\title{
Decreasing Relative Risk Aversion And Tests Of Risk Sharing ${ }^{1}$
}

\author{
Masao Ogaki AND Qiang Zhang \\ Department of Economics \\ The Ohio State University \\ Columbus, $\mathrm{OH} 43210$ \\ U.S.A.
}

Tel: (614) 2925842 (M.O.), (740) 3669436 (Q.Z.)

Email: mogaki@ecolan.sbs.ohio-state.edu, zhang.100@osu.edu

\begin{abstract}
It has often been argued that that the relative risk aversion (RRA) coefficient should decrease as a household becomes wealthier. However, existing tests of full (consumption) risk sharing hypothesis in the empirical literature are derived using preferences that exhibit either increasing or constant RRA (CRRA). We therefore use a Hyperbolic Absolute Risk Aversion (HARA) utility, which includes increasing, constant, and decreasing RRA as special cases, to test the full risk-sharing hypothesis. Using IFPRI and ICRISAT data, we find strong evidence in support of the decreasing RRA hypothesis, along with evidence favoring full risk-sharing hypothesis at the village level, and rejecting it at the inter-village level. When RRA is restricted to be constant, we replicate the previous results in the literature: reject the full risk-sharing hypothesis at both levels. Our tests, however, reject this restriction and favor decreasing RRA in almost all cases. These results suggest that it is important to allow for decreasing RRA in testing the full risk-sharing hypothesis when data containing low-income households are investigated.
\end{abstract}

Key Words: Consumption Risk Sharing/Smoothing, Relative Risk Aversion, Generalized Method of Moments

\footnotetext{
${ }^{1}$ We thank helpful comments from four anonymous referees and seminar participants at University of Illinois at Urbana-Champaign, Johns Hopkins, University of Kentucky, Ohio State, the Fourth Midwest Macroeconomics Conference at Notre Dame, and the Tow Conference on Macroeconomics at University of Iowa. Qiang Zhang acknowledges the financial support from a Dice Fellowship and a SGAES research grant from Ohio State.
} 


\section{INTRODUCTION}

The relative risk aversion (RRA) coefficient of a household whose consumption is close to the subsistence level may be very high. For example, if consumption is exactly at the subsistence level, the household may not be willing to bear any risk, and both the absolute and relative risk aversion (RRA) coefficients could be infinite. If this is the case, then the RRA coefficient must be a decreasing function of wealth for poor households. Therefore we should allow the possibility of decreasing RRA (DRRA) in testing the full risk sharing hypothesis. ${ }^{2}$ However, existing tests in the empirical literature are derived using preferences that exhibit either increasing or constant RRA even when they are applied to data containing low-income households (see, e.g. Altug and Miller (1990), Deaton (1990), Morduch (1990), Cochrane (1991), Mace (1991), Townsend (1994), Hayashi, Altonji, and Kotlikoff (1996), and Sawada (1996)). We therefore use a Hyperbolic Absolute Risk Aversion (HARA) utility, which implies increasing, constant, and decreasing RRA as special cases, to test full risk-sharing hypothesis.

Using the International Food Policy Research Institute (IFPRI) data for Pakistani households and the International Crops Research Institute of the Semi-Arid Tropics (ICRISAT) data for Indian households, we find evidence in support of the DRRA hypothesis, along with evidence favoring full risk-sharing hypothesis at the village level, and evidence against the hypothesis at the inter-village level. When RRA is restricted to be constant, we replicate the previous results in the literature: reject the full risk-sharing

\footnotetext{
${ }^{2}$ This intuition is based on our introspection. Arrow (1965), based on the boundedness of utility function, argues that RRA should increase with wealth over the whole domain of utility function, though some fluctuations in RRA are likely.
} 
hypothesis at both levels. Our tests, however, reject this restriction and favor DRRA in almost all cases. These results suggest that it is important to allow for DRRA in testing the full risk-sharing hypothesis when data containing low-income households are investigated.

A unique feature of the IFPRI data set is that food consumption and income data were collected separately from different members of each household. This feature is attractive for our purpose, because our tests, like most of the existing tests of full risk sharing, require the assumption that the measurement error in consumption is not correlated with income variables and their measurement errors. The ICRISAT data set has been used extensively in development economics. Townsend (1994) uses it to test the full risk sharing hypothesis. ${ }^{3}$ It is encouraging that our test results are qualitatively similar for these two data sets.

Existing evidence is consistent with the idea that the RRA is decreasing for lowincome households. For example, Guiso, Jappelli, and Terlizzese (1996) find that the share of risky assets in household portfolio is positively correlated with income and wealth level in data for Italian households. Kessler and Wolff (1991) find that the share of wealth invested in risky assets is, in general, increasing with wealth for French and American households. Rosenzweig and Binswanger (1993) report that Indian farmers are in general risk-averse, but the wealthier they are, the less their investment portfolios are affected by increasing weather risk. ${ }^{4}$

\footnotetext{
${ }^{3}$ Townsend (1994) experimented with subsistence consumption and found it to be insignificant. It should be noted that the exponential utility function he uses implies increasing RRA even with a positive subsistence parameter.

${ }^{4}$ Using survey data on a representative U.S. age group (51-61), Barsky et al (1997) find that RRA tends to increase slightly from the first to the third wealth quintiles and decrease slightly from the third to the fifth
} 
We present our model and derive testable implications in Section 2. In Section 3 we explain our tests for full risk sharing. The empirical results are in Section 4. Section 5 concludes the paper. The IFPRI data are described in the Data Appendix.

\section{THE MODEL}

Consider an economy with $H$ households participating in a risk-sharing pool. ${ }^{5} \mathrm{We}$ assume that preferences of each household are additively separable between consumption and leisure and are described by a discounted sum of expected felicities over time. We also assume that households have the identical time discount factor and probability beliefs on the states of the world. The Pareto-efficient consumption sharing rule is given by a programming problem (similar to that of Townsend (1994, pp.556-557)) of maximizing the weighted sum of discounted household expected utilities, subject to the resource constraint that the sum of household consumption is less than or equal to the aggregate consumption available to the pool in each period. We denote the aggregate consumption by $C_{a}(t){ }^{6}$

How RRA varies with wealth has important implications on consumption under full risk sharing. Given the welfare weights, the consumption sharing rule depends only on $C_{a}(t)$, according to the well-known Mutuality Principle. Let $C_{h}^{*}\left(C_{a}(t)\right)$ be the sharing rule for household $h$. Because of the time separability assumption for preferences,

quintiles. Barsky et al are interested in relatively low values of RRA relevant for asset pricing, hence their survey questions are not designed to detect possible very high values of RRA for poor respondents.

${ }^{5}$ Because of the subsistence parameter which will be introduced into the model, there are technical difficulties with starting from individual utility functions as described by Zhang (1998). Zhang's test results are quantitatively similar to ours when he takes these difficulties into account. 
Wilson's (1968) Theorem 5 holds in each period in the programming problem above. Hence $d C_{h}^{*} / d C_{a}$ is inversely proportional to household $h$ 's absolute risk aversion coefficient. Consumption growth, $\left(d C_{h}^{*} / d C_{a}\right) / C_{h}^{*}$, is therefore inversely related to RRA. Suppose that RRA decreases with wealth. Then the consumption growth rates of the rich households are higher than those of poor ones when $C_{a}(t)$ increases, and are lower than those of the poor ones when $C_{a}(t)$ decreases. Hence the growth rate of consumption of a rich household will fluctuate more than that of a poor one. This is in contrast with the result under constant RRA that the consumption growth rate is identical for all households in the pool.

To parameterize flexible (i.e. increasing, decreasing, or constant) RRA in a parsimonious way, we now assume that the utility function for household $h$ takes the common form

$$
u\left(C_{h}(t)\right)=\frac{\left(C_{h}(t)-\gamma\right)^{1-\alpha}-1}{1-\alpha},
$$

where $\gamma$ is the preference parameter that governs whether the RRA coefficient increases or decreases with the level of wealth. To take into account of the demographic effects in a simple form, $C_{h}(t)$ is defined as total household consumption divided by the adult equivalent household size. The RRA coefficient, $\theta_{h}$, of household $h$ implied by (1) is

$$
\theta_{h}=\alpha\left(\frac{C_{h}}{C_{h}-\gamma}\right)
$$

\footnotetext{
${ }^{6}$ The aggregate consumption depends on the history of states, but we suppress it throughout this paper to ease the exposition.
} 
If $\gamma$ is zero, (2) reduces to the constant RRA case. If $\gamma$ is positive, RRA decreases with consumption and approaches $\alpha$ asymptotically. A negative $\gamma$, on the other hand, implies that the RRA coefficient rises with consumption. A usual interpretation for positive $\gamma$ is subsistence consumption. Hence we will call it the subsistence parameter.

The intertemporal first order conditions for the programming problem imply that for any state of the world

$$
\frac{C_{h}(t+1)-\gamma}{C_{h}(t)-\gamma}=\phi(t+1),
$$

where $\phi(t+1)=[\beta \operatorname{prob}(t+1 \mid t) \mu(t) / \mu(t+1)]^{1 / \alpha}$, and $\mu(t)$ is the Lagrange multiplier associated with the resource constraint at period $t$.

Equation (3) holds for each $h$. Since $\phi(t+1)$ is independent of $h, C_{h}-\gamma$, the consumption in excess of the subsistence level, should grow at the same rate for all households in any state of the world. This is because idiosyncratic risk is insured away through the optimal risk sharing arrangements.

\section{ECONOMETRIC METHOD}

We assume that consumption is measured with error: ${ }^{7}$

$$
C_{h}^{m}(t)=C_{h}(t)+\xi_{h}(t),
$$

where $C_{h}^{m}(t)$ is measured consumption in per adult-equivalent terms, and $\xi_{h}(t)$ is measurement error. Then combining (3) and (4), we obtain

$$
C_{h}^{m}(t+1)-\phi(t+1) C_{h}^{m}(t)-\gamma+\gamma \phi(t+1)=v_{h}(t+1),
$$

\footnotetext{
${ }^{7}$ Ogaki and Atkeson (1997) discuss the choice between additive and multiplicative measurement errors. They suggest that an additive specification would be better for the purpose of testing risk sharing.
} 
where $v_{h}(t+1)=\xi_{h}(t+1)-\phi(t+1) \xi_{h}(t)$.

Now assume that $\xi_{h}(t)$ is uncorrelated with household $h$ 's permanent and current income variables and their measurement errors. Let $y_{h}^{p}$ be a proxy of its permanent income, and $y_{h}(t)$ be a measure of its current income. Let $Z_{h}(t)=\left(1, y_{h}^{p}, \Delta y_{h}(t)\right)^{\prime}$ be the vector of instrumental variables. Let $\psi=(\phi(2), \ldots, \phi(T), \gamma)$ be the $T$-dimensional vector of unknown parameters and $\psi_{0}$ be the corresponding vector of their true values. $T$ is the number of the time periods of the sample. In addition, let $f\left(C_{h}^{m}(t+1), \psi\right)$ be the 3dimensional vector

$$
\begin{aligned}
f\left(C_{h}^{m}(t+1), \psi\right) & =Z_{h}(t+1)\left[C_{h}^{m}(t+1)-\phi(t+1) C_{h}^{m}(t)-\gamma+\gamma \phi(t+1)\right] \\
& \equiv f_{h, t+1}
\end{aligned}
$$

and

$$
f_{h}(\psi)=\left(f_{h, 2}(\psi), f_{h, 3}(\psi), \ldots, f_{h, T}(\psi)\right)^{\prime} .
$$

Then we have $3(T-1)$ orthogonality conditions

$$
E_{H}\left(f_{h}\left(\psi_{0}\right)\right)=p \lim _{N \rightarrow \infty} \frac{1}{N} \sum_{h=1}^{N} f_{h}\left(\psi_{0}\right)=0
$$

where $E_{H}$ is the expectation operator over households. $\psi$ can be estimated using Hansen (1982)'s Generalized Method of Moments (GMM). ${ }^{8}$ Compared with Townsend's (1994) method for panel data, our method has the advantage of allowing for a general form of serial correlation.

\footnotetext{
${ }^{8}$ We use the Hansen/Heaton/Ogaki Gauss GMM package for estimation and testing.
} 
We consider two types of tests. The first type is the $\chi^{2}$ test of the over-identifying restrictions (i.e. Hansen's $\boldsymbol{J}$ test). Under the null hypothesis of full risk sharing, the disturbance term in (5) is uncorrelated with the income variables in the instrumental variables set. Therefore, the $\boldsymbol{J}$ test statistic has an asymptotic $\chi^{2}$ distribution. Under the alternative hypothesis of incomplete risk sharing, the disturbance in (5) will be correlated with income variables. Hence the $\boldsymbol{J}$ test statistic will tend to be large.

The other type of test is based on variable addition. We add the income difference term to (5) to obtain:

$$
C_{h}^{m}(t+1)-\phi(t+1) C_{h}^{m}(t)-\gamma+\gamma \phi(t+1)-\eta \Delta y_{h}(t+1)=v_{h}(t+1) .
$$

Under the null hypothesis of full risk sharing, $\eta=0$, because the model implies that individual income change should play no role in explaining individual consumption growth when the effects of subsistence consumption and aggregate shocks are controlled by the parameters $\gamma$ and $\phi(t)$. However, under the alternative hypothesis of incomplete risk sharing, individual income variables will affect individual consumption growth even after controlling for these effects. For example, take the alternative of Keynesian consumption function, $C_{h}=a+b y_{h}$, where $0<b<1$. Under this hypothesis, if current income is measured without errors, GMM estimation for (8) would result in $\phi(t)=1$ and $\eta=b{ }^{9}$ In our empirical work, this test is conducted at two levels. At the village level we test if the $\eta$ estimate is significantly different from zero for each village. At the pooled district level, we test if the $\eta$ estimates of all the villages in the same district are

\footnotetext{
${ }^{9}$ If current income is measured with error, the probability limit of our estimator for $\eta$ is smaller than $b$, but it is positive. So the variable addition test still has power against this alternative hypothesis.
} 
jointly significant. This is done by computing the likelihood-ratio type test statistic, which is the difference between the constrained Hansen's $\boldsymbol{J}$ statistic and the unconstrained $\boldsymbol{J}$ statistic (see, e.g. Ogaki (1993, Section 7)). The variable addition test is more directly related to the alternative hypothesis of incomplete risk sharing than Hansen's $\boldsymbol{J}$ test, and therefore is arguably more powerful. The test is similar to the ones based on regression of consumption change/growth on individual shocks frequently seen in the empirical risk sharing literature.

Another experiment that we will do is to examine what happens if we force $\gamma=0$ in the estimation and testing. Forcing $\gamma=0$ is equivalent to what other researchers have done in their tests. If we can replicate the result of rejecting the null of full risk sharing at the village level when we impose this restriction, but can not reject it when allowing $\gamma$ to be estimated, then we can be confident that it is the restriction $\gamma=0$ that is driving the rejection of the model. In turn, we can test whether or not this restriction itself is reasonable by constructing another likelihood-ratio type test.

\section{DATA}

In this section, we describe the IFPRI data collected in Pakistan. The description of the ICRISAT data can be found in Townsend (1994) and Atkeson and Ogaki (1996). The IFPRI data used in this paper cover the period from April 1986 to September $1989 .{ }^{10}$ During this period, 12 rounds of interviews were conducted at each sampled household. In each interview, a male questionnaire and a female questionnaire were used separately

\footnotetext{
${ }^{10}$ Although the survey covered at least six years, the data set does not contain consumption data for the fourth year. Hence we use the data up to 1989.
} 
for collecting different data. The male questionnaire consisted of about 170 questions and was mainly about production, marketing, financing, various revenues, male labor supply and hiring, and nonfood expenditures. The female questionnaire had around 120 questions, and was mainly about demographics, food consumption, health status of children, and female labor supply. Food consumption data included purchases of 37 food items, and consumption from gifts and own production. The original survey started with 974 households at 52 villages in four districts. These four districts were distributed in three provinces in Pakistan: Punjab, Sind, and Northwest Frontier Province. Following Townsend (1994), we use demographic information in each household to calculate maleadult-equivalent household size, according to the equivalence scales provided by Ryan, Bidinger, Pushpamma, and Rao (1985). These scales are weights assigned to each member of a household according to his/her age and sex. Specifically, the scales are: 1.0 for males 19 or older, and .9 for females of the same age group; .94 and .83 for males and females, respectively, aged between 13 and 18; for children of either gender between 7 and 12 years old, .67; for children aged 4-6, .52; for those aged 1-3, .32; and for infants, .05. In each round of the survey, the status of each member was recorded: present, traveling, or moved to a new household. The annual household size used in this paper is the weighted average of male-adult-equivalent household sizes of all rounds in a year.

The annual income and food consumption expenditure data calculated by IFRPI are used in the empirical analysis. The income measure includes nine subcategories: rental earnings in crops, net crop profits, farm wage income, non-farm income, net livestock profits, returns to capital, remittances, pension, and zakat. ${ }^{11}$ Since data on total

\footnotetext{
${ }^{11}$ Private loan association.
} 
consumption are not readily available, we test risk sharing for food consumption. Assuming that food consumption is separable from other consumption categories, the model in Section 2 applies to food consumption. We calculate a village-specific food price index using the food prices provided by IFPRI. Then we use the index to deflate food consumption and income to obtain real food consumption and real income. ${ }^{12}$ For our purpose, using food consumption is attractive for three reasons. First, our tests assume that the measurement error in reported food consumption is uncorrelated with income variables. Because food consumption and income variables are essentially collected from different household members, this assumption is more likely to be valid. Second, subsistence consumption is more likely to be important for food than for nonfood. Third, the aforementioned age-sex weights were obtained from dietary studies, and are more appropriate if used only for food consumption. It is not clear how to obtain appropriate adult-equivalent scales for nonfood consumption.

The data for Village 52 and Villages 15 to 20 are missing. We exclude from our sample the households with incomplete information on any of the following: the age-sex composition, the food consumption, and the income level for each of the three years. Concerned about sample size, we also exclude the villages with less than 11 households. As a result, in our sample, we have 633 households in 31 villages. To conserve space, we do not report detailed data information here. However, it should be helpful to note, for the purpose of interpreting the empirical results, that the three-year whole-sample average

\footnotetext{
${ }^{12}$ Although some nonfood consumption data were collected, they were in nominal terms. It is not clear to us how to obtain real nonfood consumption since prices for nonfood items were not recorded.
} 
for food consumption is 2,646 Pakistani rupee (in terms of 1986 rupee, when 1 rupee $=$ US\$.063.)

\section{EMPIRICAL RESULTS}

This section reports empirical results based on food consumption data from the IFPRI and the ICRISAT data sets. ${ }^{13}$

The test results for different districts in the Pakistani data are presented in Tables I to IV. In each table, the first row reports the baseline results in which $\gamma$ is restricted to be equal across all villages in the sample, and full risk sharing is assumed within each village by restricting $\phi(t)$ to be equal across the households in the same village. In each district, the $\boldsymbol{J}$ test in the first row does not reject the null hypothesis of full risk sharing at the five percent level. The point estimate of $\gamma$ is positive and statistically significant in all districts except for Dir. The point estimate for Dir is negative, but it is not significantly different from zero. Because the standard error for $\gamma$ is much larger for Dir than is for the other three districts, the data for Dir do not seem to contain much information about $\gamma$.

In the second, third, fourth, and fifth rows, the likelihood-ratio type test statistic, $\boldsymbol{C}$, is reported, which is the difference between the $\boldsymbol{J}$ value for each row and that for the first row. The degree of freedom for the $\boldsymbol{C}$ test in each row is the difference between the degree of freedom of each row's $\boldsymbol{J}$ test of and that of the first row. In the second row, we impose the restrictions that $\phi(t)$ is the same across villages, an implication of full risk sharing across villages. We find overwhelming evidence against the restriction for each

\footnotetext{
${ }^{13}$ The results based on Indian total consumption are similar, see Ogaki, Zhang, and Atekeson (1997).
} 
district from the $\boldsymbol{C}$ statistic reported in the second row. The third row reports the variable addition test results. A significant coefficient for income change indicates rejection of full risk-sharing for that village. We do not reject this hypothesis for most villages. The exceptions are Village 1 in Table I and Village 22 in Table III). ${ }^{14}$ The $\boldsymbol{C}$ test of this row, on the other hand, tests the joint hypothesis that all the coefficients on the income changes are equal to zero. The $\boldsymbol{C}$ test does not reject it, and hence the null hypothesis of full risk sharing within villages.

The fourth row reports the results when $\gamma$ is allowed to be different across villages. The $\boldsymbol{C}$ test does not reject the restriction that $\gamma$ is the same across villages. The fifth and sixth rows report the results when $\gamma$ is restricted to be zero. This corresponds to Townsend's (1994) model, except that he uses an exponential utility function. The $\boldsymbol{C}$ test strongly rejects this restriction in the fifth row for all districts except for Dir. The $\boldsymbol{C}$ statistic reported in the sixth row is the difference between the $\boldsymbol{J}$ value in this row and that in the fifth row. The $\boldsymbol{J}$ test in the fifth row and the $\boldsymbol{C}$ test in the sixth row test the null hypothesis of full risk sharing with constant RRA. These tests reject the null hypothesis of full risk sharing in all districts except for Dir. These results indicate that one can find evidence against full risk sharing when decreasing RRA is ignored.

Table $\mathrm{V}$ presents the results for the ICRISTA data. The test results in this table are consistent with those obtained in the IFPRI data set. The first row reports the baseline results, where the $\boldsymbol{J}$ test does not reject the null hypothesis of full risk sharing at any

\footnotetext{
${ }^{14}$ In the variable addition test, we also used the income net of remittance, which could rise and help smooth consumption in bad times. However, the test results are not qualitatively different. The income in ICRISAT data is already net of remittance, and include crop profit, labor income, profit from trade and handicrafts, and profit from animal husbandry. See Table A.I. in Townsend (1994).
} 
conventional significance level. The point estimate of $\gamma$ is positive and statistically significant. As in the Pakistani data, the results reported in the last two rows indicate that one can find evidence against full risk sharing when decreasing RRA is ignored.

\section{CONCLUSIONS}

In this paper, we have tested the full risk sharing hypothesis while taking into account the effect of estimating a parameter that allows the RRA coefficient to vary with the level of wealth. For 29 out of 31 villages in the Pakistani data, and every village in the Indian data, we do not reject the hypothesis of full risk sharing within each village. It is not surprising that we have two villages as exceptions, for Townsend (1995) finds that different villages in low-income countries have strikingly different institutional arrangements to cope with risk. We, however, find strong evidence against risk sharing across villages in both data sets. These results confirm the following intuition drawn from the information economics literature. Incomplete risk sharing can be caused by moral hazard or adverse selection, which are in turn caused by private information. It is more likely to be present in a large community, or in an economy with complicated production technologies. Without private information, various arrangements can be used by the community to share risk even if financial markets are not well developed. Hence full risk sharing can be a good approximation of the consumption growth pattern for a village economy in low-income countries. On the other hand, full risk sharing across villages, especially those far away from each other, is less likely to occur because private information may become a problem. 
When we restrict the RRA coefficient to be constant, our tests replicate the wellknown results of rejecting the full risk sharing hypothesis even within villages in both data sets, except for one district, Dir, in the Pakistani data. However, except for this district, our tests always reject this restriction in both data sets. Thus, this paper shows that misleading results may be obtained when decreasing RRA is ignored in testing full risk sharing hypothesis. In the empirical risk sharing literature, isoelastic, quadratic and exponential utility functions are often used. Because these utility functions imply either constant RRA or increasing RRA, the test results based on these preference specifications need to be interpreted with caution. 


\section{REFERENCES}

Altug, Sumru and Robert A. Miller (1990): "Household Choices in Equilibrium," Econometrica, 58, 543-570.

Arrow, Kenneth J. (1965): Aspects of the Theory of Risk-Bearing, Helsinki: Yrjö Jahnssonin säätio.

Atkeson, Andrew and Masao Ogaki (1996): "Wealth-Varying Intertemporal Elasticities of Substitution: Evidence from Panel and Aggregate Data," Journal of Monetary Economics, 38, 507-534.

Barsky, Robert B., F. Thomas Juster, Miles Kimball, and Matthew Shapiro (1997): "Preference Parameters and Behavioral Heterogeneity: An Experimental Approach in the Health and Retirement Study," Quarterly Journal of Economics 112, 537-579.

Cochrane, John (1991): “A Simple Test of Consumption Insurance,” Journal of Political Economy, 99, 957-976.

Deaton, Angus (1990): “On Risk, Insurance, and Intra-Village Smoothing,” manuscript, Princeton University.

Guiso, L., T. Jappelli, and D. Terlizzese (1996): "Income Risk, Borrowing Constraints, and Portfolio Choice," American Economic Review, 86, 158-172.

Hayashi, Fumio, Joseph Altonji, and Laurence Kotlikoff (1996): "Risk-Sharing Between and Within Families," Econometrica, 64, 261-294.

Kessler, D. and E. N. Wolf (1991): “A Comparative Analysis of Household Wealth Patterns in France and the United States," Review of Income and Wealth, 37, 249-266.

Mace, Barbara J. (1991): "Full Insurance in the Presence of Aggregate Uncertainty," Journal of Political Economy, 99, 928-956.

Morduch, Jonathan (1990): "Risk, Production, and Saving: Theory and Evidence from Indian Households," Manuscript, Harvard University.

Ogaki, Masao. (1993): "Generalized Method of Moments: Econometric Applications," in Handbook of Statistics, Vol. 11: Econometrics, edited by G. S. Maddala, C. R. Rao, and H.D. Vinod. Amsterdam: North-Holland. 
Ogaki, Masao and Andrew Atkeson (1997): "Rate of Time Preference, Intertemporal Elasticity of Substitution, and Level of Wealth," Review of Economics and Statistics, 79, 564-572.

Ogaki, Masao, Qiang Zhang, and Andrew Atkeson (1997): “A Note on Subsistence Consumption and Risk Sharing," Manuscript, Ohio State University.

Rosenzweig, M. R. and H. P. Binswanger (1993), "Wealth, Weather Risk and the Composition and Profitability of Agricultural Investments," Economic Journal, 103, $56-78$.

Sawada, Yasuyuki (1996): "A Test of Consumption Insurance in Rural Pakistan," manuscript, Stanford University.

Townsend, Robert M. (1994): "Risk and Insurance in Village India," Econometrica, 62, 539-591.

Townsend, Robert M. (1995): “Consumption Insurance: An Evaluation of the RiskBearing System in Low Income Economies," Journal of Economic Perspectives, 9, 83-102.

Wilson, Robert (1968): “The Theory of Syndicates,” Econometrica, 36, 119-132.

Zhang, Qiang (1998): "Risk Aversion, Scale Economies, and Tests of Risk Sharing," Ph.D. dissertation, The Ohio State University. 


\section{Table I GMM Results for Food Consumption- Faisalabad}

\section{(IFPRI-Pakistan)}

\begin{tabular}{|c|c|c|c|c|c|c|c|c|c|}
\hline $\begin{array}{l}\text { Risk } \\
\text { Sharing }\end{array}$ & $\gamma$ & $\begin{array}{c}\text { coeff. } \\
\Delta y_{1}(t+1)\end{array}$ & $\begin{array}{c}\text { coeff. } \\
\Delta y_{2}(t+1)\end{array}$ & $\begin{array}{l}\text { coeff. } \\
\Delta y_{3}(t+1)\end{array}$ & $\begin{array}{c}\text { coeff. } \\
\Delta y_{4}(t+1)\end{array}$ & $\begin{array}{l}\text { coeff. } \\
\Delta y_{5}(t+1)\end{array}$ & $\begin{array}{c}\text { coeff. } \\
\Delta y_{6}(t+1)\end{array}$ & $J$ & $C$ \\
\hline $\begin{array}{c}\text { Within } \\
\text { Vil. }\end{array}$ & $\begin{array}{l}1511 \\
(124)\end{array}$ & $\ldots$ & $\ldots$ & $\ldots$ & $\ldots$ & $\ldots$ & $\ldots$ & $\begin{array}{l}25.7 \\
(.316,23)\end{array}$ & $\ldots$ \\
\hline $\begin{array}{c}\text { Across } \\
\text { Vil. }\end{array}$ & $\begin{array}{r}1447 \\
(80)\end{array}$ & $\ldots$ & $\ldots$ & $\ldots$ & $\ldots$ & $\ldots$ & $\ldots$ & $\begin{array}{l}115.2 \\
(.000,33)\end{array}$ & $\begin{array}{l}89.55 \\
(.000,10)\end{array}$ \\
\hline $\begin{array}{c}\text { Within } \\
\text { Vil. }\end{array}$ & $\begin{array}{l}1474 \\
(146)\end{array}$ & $\begin{array}{l}.1659 \\
(.0797)\end{array}$ & $\begin{array}{c}.0012 \\
(.0190)\end{array}$ & $\begin{array}{c}.0361 \\
(.0316)\end{array}$ & $\begin{array}{c}-.0168 \\
(.0504)\end{array}$ & $\begin{array}{l}.0013 \\
(.0153)\end{array}$ & $\begin{array}{l}-.0046 \\
(.0108)\end{array}$ & $\begin{array}{l}19.7 \\
(.289,17)\end{array}$ & $\begin{array}{l}5.95 \\
(.429,6)\end{array}$ \\
\hline $\begin{array}{c}\text { Within } \\
\text { Vil. }\end{array}$ & $\ldots$ & $\ldots$ & $\ldots$ & $\ldots$ & $\ldots$ & $\ldots$ & $\ldots$ & $\begin{array}{l}19.7 \\
(.459,18)\end{array}$ & $\begin{array}{l}7.73 \\
(.172,5)\end{array}$ \\
\hline $\begin{array}{c}\text { Within } \\
\text { Vil. }\end{array}$ & 0 & $\ldots$ & $\ldots$ & $\ldots$ & $\ldots$ & $\ldots$ & $\ldots$ & $\begin{array}{l}71.3 \\
(.000,24)\end{array}$ & $\begin{array}{l}45.6 \\
(.000,1)\end{array}$ \\
\hline $\begin{array}{c}\text { Within } \\
\text { Vil. }\end{array}$ & 0 & $\begin{array}{l}.2808 \\
(.0699)\end{array}$ & $\begin{array}{c}.0273 \\
(.0139)\end{array}$ & $\begin{array}{c}.0134 \\
(.0308)\end{array}$ & $\begin{array}{r}-.0626 \\
(.0486)\end{array}$ & $\begin{array}{l}-.0053 \\
(.0106)\end{array}$ & $\begin{array}{c}.0002 \\
(.0105)\end{array}$ & $\begin{array}{l}49.2 \\
(.000,18)\end{array}$ & $\begin{array}{l}22.1 \\
(.001,6)\end{array}$ \\
\hline
\end{tabular}

Notes: 1. Standard errors are in parenthesis under the estimates, except for the two columns for the $\boldsymbol{J}$ and $\boldsymbol{C}$ statistics, where the numbers in parenthesis are p-value and degree of freedom, respectively. Since each village has 6 orthogonality conditions, the total number of orthogonality conditions for the baseline estimation is 36. There are 13 parameters estimated, $12 \phi(t)$ 's and $\gamma$. The degree of freedom is therefore 23. 2. The subscript of income difference term denotes village identification number, e.g. 1 for Vil. 1. 3. J is a $\chi^{2}$ statistic, and $\boldsymbol{C}$ is a likelihood-ratio type statistic. 4. The subsistence estimates for Villages 1 to 6, in the fourth row, are (with standard errors in parenthesis) as follows: 1851 (215),1467 (240), 1131 (803), 1326 (335), 1738 (206), -512 (2411), respectively. 
Table II GMM Results for Food Consumption- tto

(IFPRI-Pakistan)

\begin{tabular}{|c|c|c|c|c|c|c|c|c|c|c|c|}
\hline $\begin{array}{l}\text { Risk } \\
\text { Sharig }\end{array}$ & $\gamma$ & $\begin{array}{l}\text { coeff. } \\
\Delta *(t+1)\end{array}$ & $\begin{array}{l}\text { coeff. } \\
\Delta_{\delta}(t+1)\end{array}$ & $\begin{array}{l}\text { coeff. } \\
\Delta_{y}(t+1)\end{array}$ & $\begin{array}{l}\text { coeff. } \\
\Delta_{10}(t+1)\end{array}$ & $\begin{array}{l}\text { coeff. } \\
\Delta y_{11}(t+1)\end{array}$ & $\begin{array}{l}\text { coeff. } \\
\Delta_{12}(t+1)\end{array}$ & $\begin{array}{l}\text { coeff. } \\
\Delta_{13}(t+1)\end{array}$ & $\begin{array}{l}\text { coeff. } \\
\Delta_{14}(t+1)\end{array}$ & $J$ & $C$ \\
\hline $\begin{array}{c}\text { Within } \\
\text { Vil. }\end{array}$ & $\begin{array}{l}1867 \\
(117)\end{array}$ & $\ldots$ & $\ldots$ & $\ldots$ & $\ldots$ & $\ldots$ & $\ldots$ & $\ldots$ & $\ldots$ & $\begin{array}{l}37.8 \\
(.187,31)\end{array}$ & $\ldots$ \\
\hline $\begin{array}{c}\text { Across } \\
\text { Vil. }\end{array}$ & $\begin{array}{l}1820 \\
(77)\end{array}$ & $\ldots$ & $\ldots$ & $\ldots$ & $\ldots$ & $\ldots$ & $\ldots$ & . & $\ldots$ & $\begin{array}{c}556.9 \\
(.000,45)\end{array}$ & $\begin{array}{l}519.1 \\
(.000,14)\end{array}$ \\
\hline $\begin{array}{c}\text { Within } \\
\text { Vil. }\end{array}$ & $\begin{array}{l}1749 \\
(148)\end{array}$ & $\begin{array}{l}.0214 \\
(.0423)\end{array}$ & $\begin{array}{c}.0013 \\
(.0284)\end{array}$ & $\begin{array}{l}.0785 \\
(.0472)\end{array}$ & $\begin{array}{l}-.0304 \\
(.0163)\end{array}$ & $\begin{array}{l}.0221 \\
(.0606)\end{array}$ & $\begin{array}{l}.0257 \\
(.0211)\end{array}$ & $\begin{array}{l}-.0618 \\
(.0501)\end{array}$ & $\begin{array}{l}.0079 \\
(.0203)\end{array}$ & $\begin{array}{c}28.1 \\
(.212,23)\end{array}$ & $\begin{array}{l}9.7 \\
(.290,8)\end{array}$ \\
\hline $\begin{array}{c}\text { Within } \\
\text { Vil. }\end{array}$ & $\ldots$ & $\ldots$ & $\ldots$ & $\ldots$ & $\ldots$ & $\ldots$ & $\ldots$ & $\ldots$ & $\ldots$ & $\begin{array}{l}24.4 \\
(.441,24)\end{array}$ & $\begin{array}{l}13.4 \\
(.063,7)\end{array}$ \\
\hline $\begin{array}{c}\text { Within } \\
\text { Vil. }\end{array}$ & 0 & $\ldots$ & $\ldots$ & $\ldots$ & $\ldots$ & $\ldots$ & $\ldots$ & $\ldots$ & $\ldots$ & $\begin{array}{l}122.0 \\
(.000,32)\end{array}$ & $\begin{array}{l}82.2 \\
(.000,1)\end{array}$ \\
\hline $\begin{array}{c}\text { Within } \\
\text { Vil. }\end{array}$ & 0 & $\begin{array}{c}.0525 \\
(.0397)\end{array}$ & $\begin{array}{c}.0437 \\
(.0184)\end{array}$ & $\begin{array}{l}.0151 \\
(.0161)\end{array}$ & $\begin{array}{c}-.0573 \\
(.0135)\end{array}$ & $\begin{array}{l}.0199 \\
(.0640)\end{array}$ & $\begin{array}{l}.0509 \\
(.0171)\end{array}$ & $\begin{array}{l}-.0736 \\
(.0557)\end{array}$ & $\begin{array}{c}.0387 \\
(.0140)\end{array}$ & $\begin{array}{l}57.8 \\
(.000,24)\end{array}$ & $\begin{array}{l}64.2 \\
(.000,8)\end{array}$ \\
\hline
\end{tabular}

See the notes for Table I. The subsistence level estimates for Villages 7 to 14, in the fourth row, are (with standard errors in parenthesis): 1998 (294), 1978 (172), -1445 (2175), 1936 (347), 1532 (607), 2018 (259), $1.9 e+5$ (1.9e+7), 2256 (265), respectively. 
Table III GMM Results for Food Consumption- adin

(IFPRI-Pakistan)

\begin{tabular}{|c|c|c|c|c|c|c|c|c|c|c|c|c|c|c|}
\hline $\begin{array}{l}\text { Risk } \\
\text { Sharig }\end{array}$ & $\gamma$ & $\begin{array}{l}\text { coeff. } \\
\Delta_{21} t+1\end{array}$ & $\begin{array}{l}\text { coeff. } \\
\Delta_{2} t+1\end{array}$ & $\begin{array}{l}\text { coeff. } \\
\Delta_{23} t+1\end{array}$ & $\begin{array}{l}\text { coeff. } \\
\Delta_{22^{t+1}}\end{array}$ & $\begin{array}{l}\text { coeff. } \\
\Delta_{25}+1\end{array}$ & $\begin{array}{l}\text { coeff. } \\
\Delta_{20}{ }^{t+1}\end{array}$ & $\begin{array}{l}\text { coeff. } \\
\Delta \Delta_{y}{ }^{t+1}\end{array}$ & $\underset{\Delta=w_{w}}{\text { coeff. }}$ & $\begin{array}{l}\text { coeff. } \\
\Delta_{3^{t}}+1\end{array}$ & $\begin{array}{l}\text { coeff. } \\
\Delta_{37}+1\end{array}$ & $\underbrace{\text { coeff. }}_{\Delta{ }_{30},+1}$ & $J$ & $C$ \\
\hline $\begin{array}{c}\text { Within } \\
\text { Vil. }\end{array}$ & $\begin{array}{l}1441 \\
(84)\end{array}$ & $\ldots$ & $\ldots$ & $\ldots$ & $\ldots$ & $\ldots$ & $\ldots$ & $\ldots$ & $\ldots$ & $\ldots$ & $\ldots$ & $\ldots$ & $\begin{array}{l}44.2 \\
(.420,43)\end{array}$ & \\
\hline $\begin{array}{c}\text { Across } \\
\text { Vil. }\end{array}$ & $\begin{array}{l}1701 \\
(48)\end{array}$ & $\ldots$ & $\ldots$ & $\ldots$ & $\ldots$ & $\cdots$ & $\ldots$ & $\ldots$ & $\ldots$ & $\ldots$ & $\ldots$ & $\ldots$ & $\begin{array}{c}326.0 \\
(.000,63)\end{array}$ & $\begin{array}{c}282.2 \\
(.000,20)\end{array}$ \\
\hline $\begin{array}{c}\text { Within } \\
\text { Vil. }\end{array}$ & $\begin{array}{l}1434 \\
(100)\end{array}$ & $\begin{array}{l}.046 \\
(.038)\end{array}$ & $\begin{array}{l}.110 \\
. .050)\end{array}$ & $\begin{array}{l}-.047 \\
(.046)\end{array}$ & $\begin{array}{l}.002 \\
(.067)\end{array}$ & $\begin{array}{l}.019 \\
(.012)\end{array}$ & $\begin{array}{l}.015 \\
(.022)\end{array}$ & $\begin{array}{l}.005 \\
(.013)\end{array}$ & $\begin{array}{l}.025 \\
(.036)\end{array}$ & $\begin{array}{l}.044 \\
(.034)\end{array}$ & $\begin{array}{c}.046 \\
(.036)\end{array}$ & $\begin{array}{l}.029 \\
(.032)\end{array}$ & $\begin{array}{l}28.8 \\
(.630,32)\end{array}$ & $\begin{array}{l}15.4 \\
(.165,11)\end{array}$ \\
\hline $\begin{array}{c}\text { Within } \\
\text { Vil. }\end{array}$ & $\ldots$ & $\ldots$ & $\cdots$ & $\ldots$ & $\ldots$ & $\ldots$ & $\ldots$ & $\ldots$ & $\ldots$ & $\ldots$ & $\ldots$ & $\ldots$ & $\begin{array}{l}29.4 \\
(.647,33)\end{array}$ & $\begin{array}{l}14.8 \\
(.140,10)\end{array}$ \\
\hline $\begin{array}{c}\text { Within } \\
\text { Vil. }\end{array}$ & 0 & & $\ldots$ & & & & $\ldots$ & & $\ldots$ & $\ldots$ & $\ldots$ & $\ldots$ & $\begin{array}{l}92.9 \\
(.000,44)\end{array}$ & $\begin{array}{c}48.7 \\
(.000,1)\end{array}$ \\
\hline $\begin{array}{c}\text { Within } \\
\text { Vil. }\end{array}$ & 0 & $\begin{array}{c}.040 \\
(.038)\end{array}$ & $\begin{array}{l}.124 \\
.052)\end{array}$ & $\begin{array}{l}-.079 \\
(.042)\end{array}$ & $\begin{array}{c}.041 \\
(.066)\end{array}$ & $\begin{array}{l}.027 \\
(.013)\end{array}$ & $\begin{array}{l}.051 \\
(.011)\end{array}$ & $\begin{array}{l}-.010 \\
(.012)\end{array}$ & $\begin{array}{l}.047 \\
(.036)\end{array}$ & $\begin{array}{l}.033 \\
(.028)\end{array}$ & $\begin{array}{l}.040 \\
(.035)\end{array}$ & $\begin{array}{l}-.005 \\
(.020)\end{array}$ & $\begin{array}{l}50.4 \\
(.000,33)\end{array}$ & $\begin{array}{c}42.5 \\
(.000,11)\end{array}$ \\
\hline
\end{tabular}

See the notes for Table I. The subsistence level estimates for Villages 21 to 39, in the fourth row, are (with standard errors in parenthesis): 1627 (385), 2018 (74), 1625 (147), 1760 (86), 1850 (18), 1254 (138), 1453 (334), 1405 (174), 2082 (221), 7172 $(2 e+5), 1768(355)$, respectively. 
Table I GMM Results for Food Consumption- ir (IFPRI-Pakistan)

\begin{tabular}{|c|c|c|c|c|c|c|c|c|c|}
\hline $\begin{array}{l}\text { Risk } \\
\text { Sharing }\end{array}$ & $\gamma$ & $\begin{array}{c}\text { coeff. } \\
\Delta_{41}(t+1)\end{array}$ & $\begin{array}{l}\text { coeff. } \\
\Delta_{42}(t+1)\end{array}$ & $\begin{array}{l}\text { coeff. } \\
\Delta_{45}(t+1)\end{array}$ & $\begin{array}{c}\text { coeff. } \\
\Delta_{4}(t+1)\end{array}$ & $\begin{array}{l}\text { coeff. } \\
\Delta_{48}(t+1)\end{array}$ & $\begin{array}{l}\text { coeff. } \\
\Delta_{51}(t+1)\end{array}$ & $J$ & $C$ \\
\hline $\begin{array}{c}\text { Within } \\
\text { Vil. }\end{array}$ & $\begin{array}{l}-207 \\
(905)\end{array}$ & $\ldots$ & $\ldots$ & $\ldots$ & $\ldots$ & $\ldots$ & $\ldots$ & $\begin{array}{c}19.8 \\
(.652,23)\end{array}$ & $\ldots$ \\
\hline $\begin{array}{c}\text { Across } \\
\text { Vil. }\end{array}$ & $\begin{array}{l}976 \\
(387)\end{array}$ & $\ldots$ & $\ldots$ & $\ldots$ & $\ldots$ & $\ldots$ & $\ldots$ & $\begin{array}{l}58.3 \\
(.004,33)\end{array}$ & $\begin{array}{l}38.48 \\
(.000,10)\end{array}$ \\
\hline $\begin{array}{c}\text { Within } \\
\text { Vil. }\end{array}$ & $\begin{array}{l}-317 \\
(1555)\end{array}$ & $\begin{array}{l}.0387 \\
(.0340)\end{array}$ & $\begin{array}{l}.0019 \\
(.0324)\end{array}$ & $\begin{array}{l}-.0003 \\
(.0110)\end{array}$ & $\begin{array}{l}.0024 \\
(.0064)\end{array}$ & $\begin{array}{l}-.0055 \\
(.0202)\end{array}$ & $\begin{array}{l}.0235 \\
(.0261)\end{array}$ & $\begin{array}{l}15.2 \\
(.570,17)\end{array}$ & $\begin{array}{l}4.62 \\
(.593,6)\end{array}$ \\
\hline $\begin{array}{c}\text { Within } \\
\text { Vil. }\end{array}$ & $\ldots$ & $\ldots$ & $\ldots$ & $\ldots$ & $\ldots$ & $\ldots$ & $\ldots$ & & \\
\hline $\begin{array}{c}\text { Within } \\
\text { Vil. }\end{array}$ & 0 & $\ldots$ & $\ldots$ & $\ldots$ & $\ldots$ & $\ldots$ & $\ldots$ & $\begin{array}{l}19.9 \\
(.703,24)\end{array}$ & $\begin{array}{l}.06 \\
(.806,1)\end{array}$ \\
\hline $\begin{array}{c}\text { Within } \\
\text { Vil. }\end{array}$ & 0 & $\begin{array}{c}.0380 \\
(.0339)\end{array}$ & $\begin{array}{c}.0035 \\
(.0318)\end{array}$ & $\begin{array}{c}.0008 \\
(.0098)\end{array}$ & $\begin{array}{c}.0022 \\
(.0063)\end{array}$ & $\begin{array}{l}-.0088 \\
(.0139)\end{array}$ & $\begin{array}{l}.0018 \\
(.0186)\end{array}$ & $\begin{array}{l}17.2 \\
(.511,18)\end{array}$ & $\begin{array}{l}2.7 \\
(.845,6)\end{array}$ \\
\hline
\end{tabular}

See the notes for Table I. No convergence achieved for the fourth row. 


\section{Table GMM Results for Food Consumption}

\section{ICRI T-India}

\begin{tabular}{|c|c|c|c|c|c|c|c|c|}
\hline $\begin{array}{l}\text { Risk } \\
\text { Sharing }\end{array}$ & $\gamma_{A}$ & $\gamma_{S}$ & $\gamma_{K}$ & $\begin{array}{c}\text { coeff. } \\
\Delta y_{A}(t+1)\end{array}$ & $\begin{array}{c}\text { coeff. } \\
\Delta y_{S}(t+1)\end{array}$ & $\begin{array}{c}\text { coeff. } \\
\Delta y_{K}(t+1)\end{array}$ & $J$ & $C$ \\
\hline $\begin{array}{c}\text { Within } \\
\text { Vil. }\end{array}$ & $\begin{array}{l}237.3 \\
(15.2)\end{array}$ & 237.3 & 237.3 & $\ldots$ & $\ldots$ & $\ldots$ & $\begin{array}{l}46.2 \\
(.507,47)\end{array}$ & $\ldots$ \\
\hline $\begin{array}{c}\text { Across } \\
\text { Vil. }\end{array}$ & $\begin{array}{l}269.7 \\
(14.0)\end{array}$ & 269.7 & 269.7 & $\ldots$ & $\ldots$ & $\ldots$ & $\begin{array}{l}1239.4 \\
(.000,63)\end{array}$ & $\begin{array}{c}1193.2 \\
(.000,16)\end{array}$ \\
\hline $\begin{array}{c}\text { Within } \\
\text { Vil. }\end{array}$ & $\begin{array}{l}238.4 \\
(16.1)\end{array}$ & 238.4 & 238.4 & $\begin{array}{l}.024 \\
(.013)\end{array}$ & $\begin{array}{c}.011 \\
(.011)\end{array}$ & $\begin{array}{c}.005 \\
(.016)\end{array}$ & $\begin{array}{c}41.3 \\
(.589,44)\end{array}$ & $\begin{array}{c}4.88 \\
(.181,3)\end{array}$ \\
\hline $\begin{array}{c}\text { Within } \\
\text { Vil. }\end{array}$ & $\begin{array}{l}237.9 \\
(21.4)\end{array}$ & $\begin{array}{l}233.1 \\
(30.3)\end{array}$ & $\begin{array}{l}240.5 \\
(30.6)\end{array}$ & $\ldots$ & $\ldots$ & $\ldots$ & $\begin{array}{c}46.1 \\
(.425,45)\end{array}$ & $\begin{array}{c}.03 \\
(.985,2)\end{array}$ \\
\hline $\begin{array}{c}\text { Within } \\
\text { Vil. }\end{array}$ & 0 & 0 & 0 & $\ldots$ & $\ldots$ & $\ldots$ & $\begin{array}{c}114.5 \\
(.000,48)\end{array}$ & $\begin{array}{c}68.3 \\
(.000,1)\end{array}$ \\
\hline Within & & & & & & & & \\
\hline Vil. & 0 & 0 & 0 & $\begin{array}{l}.012 \\
(.011)\end{array}$ & $\begin{array}{l}.033 \\
(.010)\end{array}$ & $\begin{array}{c}.012 \\
(.016)\end{array}$ & $\begin{array}{c}102.3 \\
(.000,45)\end{array}$ & $\begin{array}{c}12.2 \\
(.007,3)\end{array}$ \\
\hline
\end{tabular}

See the notes for Table I. Subscripts A, S, and K denote Aurepalle, Shirapur, and Kanzara, respectively. 